\title{
The role of perfluooctanoic acid (PFOA) in airway hyperrepsoniveness
}

\author{
Mark Loewen*, Sujata Basu, Andrew Halayko, Kent HayGlass, Genevieve Bondy, Allan Becker \\ From AllerGen NCE Inc.'s Fifth Annual Research Conference: Innovation from Cell to Society \\ Québec City, QC, Canada. 7-9 February 2010
}

\section{Objective/purpose}

Evidence is emerging that human exposure to environmentally ubiquitous perfluorooctanoic acid (PFOA), used commonly for its household stain repellency characteristics, is associated with immunologic changes. Data from adults near an industrial PFOA disposal site demonstrated a strong negative correlation between blood PFOA concentrations and some immune responses. We propose to test if early life exposures to PFOA are playing a role in modifying airway responses.

\section{Methods}

Although several animal exposure models have been used to test ingestible PFOA toxicity using gavage methods at high concentrations, we chose to expose timedpregnant Balb/C dams from GD-2 at more environmentally relevant concentrations $(4 \mathrm{mg} / \mathrm{kg}$ diet PFOA Sigma Aldrich) mixed into the diet (Purina 5001). Dams were allowed to eat either a control or contaminated diet adlibitum ( 4-6 g/day) through pregnancy and lactation. Upon weaning, lung mechanics of the exposed and control dams were measured using a flexiVent and liver weights measured. Dams were not sensitized to allergen.

\section{Findings}

Baseline lung mechanics and airway responsiveness of PFOA-exposed, non-sensitized mice were not significantly different from controls, however, liver weight as a function of body weight was significantly higher in exposed dams compared to controls $(9.4 \%$ vs $5.5 \% \mathrm{p}=$ 0.0003).

\section{Deliverables and relevance}

The importance of studying the effects in pregnancy and early life was demonstrated by observations of PFOA

University of Manitoba, Health Canada Food Directorate, Canada exposures in pregnant mice where offspring died, while the mother seemed unaffected. In that study, mortality of the pups was attributed to pulmonary abnormalities.

We have demonstrated that environmentally relevant exposures to PFOA in pregnant mice yield significant increases in liver weight. We will investigate lung function in the offspring of these dams. Pups from exposed and control dams are being weaned on the same diet as their mother. The exposed and control groups have been divided into 2 further groups one of which has been sensitized intraperitoneally at day 29 and 46 and intranasally at days 46,47 and 48 with ovalbumin. Cytokines and WBC in BALF, IgE in blood and lung mechanics using flexiVent will be measured and reported.

Published: 26 November 2010

doi:10.1186/1710-1492-6-S3-P21

Cite this article as: Loewen et al:: The role of perfluooctanoic acid (PFOA) in airway hyperrepsoniveness. Allergy, Asthma \& Clinical Immunology 2010 6(Suppl 3):P21.

Submit your next manuscript to BioMed Central and take full advantage of:

- Convenient online submission

- Thorough peer review

- No space constraints or color figure charges

- Immediate publication on acceptance

- Inclusion in PubMed, CAS, Scopus and Google Scholar

- Research which is freely available for redistribution 